\title{
Effect of computer aided learning (CAL) in promoting cognitive learning of sixth grade children of Government schools in Ludhiana district
}

\author{
ARSHPREET KAUR* AND VARINDER RANDHAWA \\ Department of Home Science Extension and Communication Management, Punjab Agricultural \\ University, LUDHIANA(PUNJAB) INDIA
}

\begin{abstract}
The thrust of the present study was to study the 'Effect of Computer aided learning in promoting cognitive learning of sixth grade children of government schools in Ludhiana district'. It used experimental research design to collect the data. The field experiment was conducted to assess the promotion of cognitive learning at first two taxonomic levels i.e. Knowledge and Comprehension (Bloom et al., 1956) through the CAL package introduced under Sarv Shikhya Abhiyan. For this purpose randomized pre-test and post-test research design was used. Two matching groups of 25 students each studying in class $6^{\text {th }}$ in the Government senior secondary schools of two adjoining villages in Ludhiana district were assigned treatment by random methods. The experimental group was taught through CAL and treated as intervention mode $1\left(\mathrm{IM}_{1}\right)$, whereas control group was taught through traditional method and treated as intervention mode $2\left(\mathrm{IM}_{2}\right)$. The results revealed that $\mathrm{IM}_{1}$ i.e. $\mathrm{CAL}$ was more effective as compared to $\mathrm{IM}_{2}$ i.e. traditional teaching method. The gain in cognition scores was found to be significantly higher in case of $\mathrm{IM}_{1}$ as compared to $\mathrm{IM}_{2}$ in case of all seven lessons.
\end{abstract}

Key Words : Computer aided learning, Cognitive learning, Traditional method

View Point Article : Kaur, Arshpreet and Randhawa, Varinder (2016). Effect of computer aided learning (CAL) in promoting cognitive learning of sixth grade children of Government schools in Ludhiana district. Internat. J. Home Sci. Extn. \& Comm. Manage., 3 (1): 26-30.

Article History : Received : 03.08.2015; Revised : 15.12.2015; Accepted : 26.12.2015

\footnotetext{
* Author for correspondence
} 